\title{
NOx Elimination and Drainage NP Elimination Should Be Stopped for The Production of Fish and for The Protection of Global Warming
}

\author{
Shoichiro Ozaki" \\ The Institute of Physical and Chemical Research 2-1 Hirosawa, Japan
}

"Corresponding author: Shoichiro Ozaki, The Institute of Physical and Chemical Research 2-1 Hirosawa, Wakoshi Saitama 3510198, Japan. Tel: +810467670991; Email: ozaki-0991@jcom.zaq.ne.jp

Citation: Ozaki S (2017) NOx Elimination and Drainage NP Elimination Should Be Stopped for The Production of Fish and for The Protection of Global Warming. J Fish Aqua Dev: JFAD-125. DOI:10.29011/JFAD-125/100025

Received Date: 18 September, 2017; Accepted Date: 23 September, 2017; Published Date: 3 October, 2017

\begin{abstract}
NOx is promoting plankton growth and fish production. Much NOx is produced when fossil is burned. Many governments set up the law to eliminate NOx by the reason NOx is pollution gas and not good for health. And also Drainage NP are eliminated. Some other many governments are welcoming NOx as fertilizer for plant and encouraged the use of NOx and Drainage NP for plankton growth and getting many fish.

The balance of materials which concerned in burning of fossil and $\mathrm{CO} 2$ assimilation are summarized. It was found that NOx produced by burning and drainage NP are so much and effective use of NOx and drainage NP is a key to control of climate of earth and production of grain and fish production. NOx elimination and Drainage NP elimination should be stopped for the production of grain and fish and for the protection of global warming
\end{abstract}

Keywords: Carbon dioxide; Fish production $\mathrm{CO}_{2}$ assimilation; Global warming; NOx

\section{Introduction}

The earth is warmed by the fossil fuel burning releasing $\mathrm{CO}_{2}$ and heat. The plant is growing by $\mathrm{CO}_{2}$ assimilation absorbing $\mathrm{CO}_{2}$ producing carbohydrate and $\mathrm{O}_{2}$. If we can compensate the generation of $\mathrm{CO}_{2}$ and heart with the absorption of $\mathrm{CO}_{2}$ and heart by $\mathrm{CO}_{2}$ assimilation, global warming can be protected [1-12].

Plankton photosynthesis are studied by many investigators [13-38]. These studies indicate that $\mathrm{CO}_{2}$ assimilation is playing very important role for the regulation of climate. Supply of nutrients are important factor for the promotion of $\mathrm{CO}_{2}$ assimilation. When fossil fuel burned, much NOx is produced. Too much burning and too much $\mathrm{CO}_{2}$ is produced and, $\mathrm{CO}_{2}$ concentration is increasing. Protection of global warming is now one of biggest concern of the world. For the protection of global warming, $\mathrm{CO}_{2}$ must be diminished. Promotion of $\mathrm{CO}_{2}$ assimilation is most effective way. To promote $\mathrm{CO}_{2}$ assimilation, Increase of nutrient $\mathrm{N}$ and $\mathrm{P}$ are most effective way. NOx is a major nitrogen source for the plant to grow. But NOx is hated as pollution gas and many governments like Japan, United State, Germany, England be fixed well. As the result, $\mathrm{CO}_{2}$ concentration increasing. And global warming is observed.

On the contrary, many countries like China, India, Indonesia, Vietnam do not eliminate NOx and they are using NOx as fertilizer. Then much plankton is produced and much $\mathrm{CO}_{2}$ are fixed and much fish is produced. I wish to describe these facts in detail.

\section{Material Balance of $\mathrm{CO}_{2}$ Assimilation Related Compounds}

Amount of $\mathrm{CO}^{2}$, NOx, plankton, Grain, Fish and Grass Tree and increase of $\mathrm{CO}_{2}$ in the world are shown in (Table 1).

$\mathrm{CO}_{2} 300$ Billion tone $\mathrm{CO}_{2}$ was produced in the world in 2016 by the burning of 140 billion tone fossil. NOx 12 billion tone NOx is produced in the process of burning.

Plankton from 300 billion tone $\mathrm{C} \mathrm{O}_{2}, 40$ billion tone plankton, is estimated to be produced Grain from 300 million tone, 33 million tone grain are produced Grass, Tree from 300 million tone $\mathrm{CO}_{2}, 226$ billion tone grass and tree are estimate to be produced. Fish from 40 billion tone plankton, 2 billion tone fish are produced. $1 / 3$ tone fossil give 1 tone $\mathrm{CO}_{2} 1$ tone $\mathrm{CO}_{2}$ produce $1 / 25$ tone $\mathrm{NOx}$ as by product in the burning process, In the $\mathrm{CO}_{2}$ assimilation process, 1 tone $\mathrm{CO}_{2}$ react with 18/44 tone $\mathrm{H} 20$ using 1/25 tone NOx 


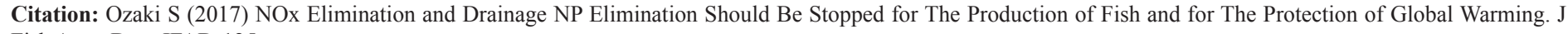
Fish Aqua Dev: JFAD-125.

$\mathrm{CO}_{2}$, Grain and Fish production are obtained from statistic. Plankton weight is estimated from the fact that sardine eat 10 times plankton of his weight. And Tuna (Maguro) eat 10 times sardine of his weight. Then we estimated that fish eat 20 times plankton of his weight. In average. Grass Tree weight is obtained from $\mathrm{CO}_{2}$ weight minus plankton and Grain weight.

\begin{tabular}{|c|c|c|c|c|c|c|c|}
\hline & $\begin{array}{c}\mathrm{CO}_{2} \text { Billion } \\
\text { tone }\end{array}$ & NOx & plankton & Grain & Fish & Grass Tree & $\mathrm{CO}_{2}$ increase \\
\hline World & 300 & 12 & 40 & 33 & 2 & 225 & \\
\hline China & 100 & 4 & 5.5 & 5.5 & 0.794 & 78.6 & 0 \\
\hline India & 24 & 1 & 2 & 2.9 & 0.1 & 19.1 & 0 \\
\hline USA & 51 & 1 & 1.2 & 4.4 & 0.06 & 45.4 & 0 \\
\hline Russia & 17 & 0.6 & 0.92 & 0.9 & 0.046 & 15.2 & 0 \\
\hline Japan & 12 & 0.48 & 0.92 & 0.12 & 0.046 & 11 & 9 \\
\hline Germany & 7.8 & 0.31 & 0.058 & 0.47 & 0.0029 & 7.3 & 0 \\
\hline Canada & 5.8 & 0.23 & 0.055 & 0.66 & 0.0105 & 5.1 & 0 \\
\hline UK & 4 & 0.16 & 0.018 & 0.2 & 0.0091 & 3.8 & 0.016 \\
\hline Italia & 3.6 & 0.14 & 0.039 & 0.16 & 0.0024 & 3.4 & 0.003 \\
\hline France & 3.3 & 0.13 & 0.013 & 0.67 & 0.0067 & 3.2 & 0 \\
\hline
\end{tabular}

Table 1: Amount of $\mathrm{CO}_{2}$, NOx, plankton, Grain, Fish Grass Tree and $\mathrm{CO}_{2}$ increase of 10 counts.

\section{$\mathrm{CO}_{2}$, NOx and Heat Balance in the World}

Fossil fuel $1.4 \times 10^{10}$ tone was burned at whole world in 2015 and about $4.4 \times 10^{10}$ tone $\mathrm{CO}_{2}$ and $7.4 \times 10^{15} \mathrm{kcal}$ were produced and $2.5 \times 10^{9}$ tone NOx is produced. If we use this $2.5 \times 10^{9}$ tone NOx for $\mathrm{CO}_{2}$ assimilation, we can fix $\mathrm{CO}_{2} 50 \times 10^{9}$ tone $(25 \times 2.5$ $\mathrm{x} 10^{9}$ ). The amount of NOx produced is around $2.5 \times 10^{9}$ tone in whole world. To eliminate NOx $2.5 \times 10^{9}$ tone, equimolar ammonia 11.3 billion ton is used. To make ammonia11.3 billion tone, 2 billion tone hydrogen gasie used. To make 2 billion tone hydrogen, butane 6.4 billion tone is used. As the result, 17.6 billion tone $\mathrm{CO}_{2}$ is released. If NOx elimination is stopped, 17.6 billion tone $\mathrm{CO}_{2}$ release can be stopped. And 17.6x 25=440 billion tone $\mathrm{CO}_{2}$ can be fixed.

\section{$\mathrm{CO}_{2}, \mathrm{NOx}$ and Heat Balance in Japan}

Fossil fuel $1.4 \times 10^{10}$ tone was burned at Japan in 2015 and about $4.4 \times 10^{10}$ tone $\mathrm{CO} 2$ and $7.4 \times 10^{13} \mathrm{kcal}$ were produced and
$2 \times 10^{6}$ tone NOx is produced. In Japan, 2.8x $10^{8}$ hector wood is present. 13.7 tone $\mathrm{CO}_{2}$ is fixed at 1 hector wood in one year. $2.8 \times 10^{8} \times 13.7=3.8 \times 10^{9}$ tone $\mathrm{CO}_{2}$ can be fixed at wood. In Japan, $4.5 \times 10^{7}$ hector cultivated land is present. 14.7 tone $\mathrm{CO}_{2}$ is fixed at 1 hector in one year. $4.5 \times 10^{7} \times 14.7=6,3 \times 10^{8}$ tone $\mathrm{CO} 2$ can be fixed in one year at cultivated land. Therefore $3.8 \times 10^{9}+6,3 \mathrm{x}$ $10^{8}=4.4 \times 10^{9}$ tone $\mathrm{CO}_{2}$ is fixed at land. This is far from production of $\mathrm{CO}_{2}$. Therefore we must promote $\mathrm{CO}_{2}$ assimilation by the supply of nutrient N, NOx at sea.

\section{Effective use of NOx and Drainage NP are Es- sential for Protection of Global Warming and Fish Production}

Fish production along with $\mathrm{CO}_{2}$ emission, $\mathrm{NOx}$ emission and $\mathrm{CO}_{2}$ fixed by plankton $\mathrm{CO}_{2}$ assimilation of the world are shown at (Table 2).

\begin{tabular}{|c|c|c|c|c|c|c|c|}
\hline & $\begin{array}{l}\text { Fish production } \\
\text { (2016) }\end{array}$ & $\begin{array}{l}\text { Million tone } \\
\text { (1997) }\end{array}$ & $\mathrm{CO}_{2}$ emission & NOx emission & $\begin{array}{l}\text { Million tone } \\
\quad(2002)\end{array}$ & $\begin{array}{l}\text { Population } \\
\text { billion }\end{array}$ & $\begin{array}{c}\mathrm{CO}_{2} \text { fixed by } \\
\text { plankton }\end{array}$ \\
\hline World & 200 & 93.19 & 93.33 & 4400 & 100 & 76 & 2000 \\
\hline Top China & 79.38 & 16.77 & 16.29 & 1064 & 50 & 13.5 & 794 \\
\hline 2nd Indonesia & 22.21 & 4.65 & 5.55 & 50 & & 2.39 & 222 \\
\hline India & 10.11 & 3.72 & 3.60 & 245 & & 12.24 & 101 \\
\hline Vietnam & 6.21 & & & 21 & & 0.86 & 62 \\
\hline USA & 6.05 & 4.65 & 5.41 & 517 & & 3.10 & 60 \\
\hline Peru & 4.92 & 8.38 & 7.87 & & & 0.28 & 49 \\
\hline
\end{tabular}




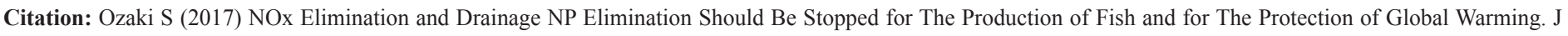
Fish Aqua Dev: JFAD-125.

\begin{tabular}{|c|c|c|c|c|c|c|c|}
\hline Japan & 4.64 & 4.65 & 5.88 & 125 & 2 & 1.27 & 46 \\
\hline Russia & 4.61 & 3.72 & 4.66 & 176 & & 1.43 & 46 \\
\hline Philippine & 4.50 & & & 11 & & 0.92 & 45 \\
\hline Norway & 3.52 & & 2.87 & 52 & & 0.48 & 35 \\
\hline Bangladesh & 3.68 & & & & & 1.62 & 37 \\
\hline Korea & 3.33 & 6.1 & 58 & & & 0.4 & 33 \\
\hline Chile & 3.19 & 4.65 & 5.87 & 8 & & 0.17 & 32 \\
\hline Myanmar & 2.95 & & & & & 0.53 & 30 \\
\hline Tai & 2.59 & & & 28 & & 0.63 & 26 \\
\hline Malaysia & 2.00 & & & 26 & & 0.28 & 20 \\
\hline Mexico & 1.69 & & & 47 & & 1.23 & 17 \\
\hline Egypt & 1.51 & & & 23 & & 0.94 & 15 \\
\hline Taiwan & 1.30 & & & & & 0.27 & 13 \\
\hline Brazil & 1.27 & & & 48 & & 2.08 & 13 \\
\hline Spain & 1.26 & & & 26 & & 0.46 & 13 \\
\hline Canada & 1.05 & & & 55 & & 0.37 & 10 \\
\hline Nigeria & 1.92 & & & 87 & & 1.94 & 19 \\
\hline Iran & 0.98 & & & 63 & & 0.80 & 10 \\
\hline U kingdom & 0.91 & & & 40 & & 0.66 & 10 \\
\hline Argentine & 0.81 & & & 19 & & 0.44 & 8 \\
\hline France & 0.71 & & & 32 & & 0.67 & 7 \\
\hline Turkey & 0.67 & & & 38 & & 0.80 & 7 \\
\hline Pakistan & 0.64 & & & 17 & & 1.98 & 6 \\
\hline South Africa & 0.57 & & & 42 & & 0.33 & 6 \\
\hline Netherland & 0.44 & & & 18 & & 0.17 & 4 \\
\hline Italia & 0.34 & & & 35 & & 0.60 & 4 \\
\hline Germany & 0.29 & & & 77 & & 0.83 & 3 \\
\hline Australia & 0.25 & & & 35 & & 0.25 & 3 \\
\hline
\end{tabular}

Table 2: Fish production, $\mathrm{CO}_{2}$ emission and $\mathrm{NOx}$ emission of the world.

World fish production in 2016 increased to 200 million tone, about double of 93 million tone in 1997 and 2002. China 79.38 million tone, Indonesia22.21, India10.11, Vietnam 6.21 increasing fish production very much.

China, Indonesia, India, Vietnam do not eliminate NOx and do not do drainage treatment They use NOx and excreta as it is for production of plankton and fish. Therefore, fish production increased remarkably at the district where no N, P supply by counter current of nutrient rich deep sea water with nutrient poor shallow sea water.

China produced fish 16.77 million tone fish in 2002. And 79.38 million tone fish in 2016. This is huge Increase. China produced 4 billion tone NOx. This NOx is released to air and dissolved in rain and give enough nutrient nitrogen to sea, lake and river to grow 4.4 billion tone plankton and 79.38 million tone fish. This 4 billion tone NOx became enough fertilizer for the production of 4.4 billion tone grain. And also this 4 billion tone NOx contributed for the growth of grass and tree. These three $\mathrm{CO}_{2}$ assimilation action, plankton formation, grain production and grass tree growth, fixed 100 billion tone $\mathrm{CO}_{2}$ and are contributing for the protection of global warming.

Japan produced 16 million tone fish, top in the world in 1960 But fish production decreased to 4.64 million tone 7 th place in 2016. This is huge decrease. Japan is eliminating 3 million tone $\mathrm{N}$ and $\mathrm{P}$ since 1980. Therefore, NP concentration of sea decreased remarkably. Plankton cannot grow at this low concentration. Therefore, fish decreased. 12 million tone fish was not produced in recent years. Especially, Pacific Saury (sanma)decreased, 2006 $3 \times 10^{5}$ t, $20141.5 \times 10^{5}$ t, Sardin (Iwashi) 19884.81 million tone 20140.5 million tone these 2 fishs eat plankton. Tuna (maguro) 


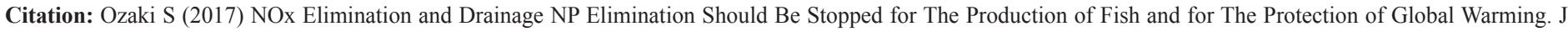
Fish Aqua Dev: JFAD-125.

which eat Pacific Saury and Sardin decreased 19610.16 million tone 20140.017 million tone.

Bonit (Katsuo), Bream(Tai), Sea eel (Anago) decreased, Salmon(Sake), Mackerel (Saba), Octopus (Tako), Squid (Ika), Eel (Unagi), Sea eel (Anago), 0.16 million tone in 1969 to 0.017 million tone in 2014. Asari 0.1 million tone in 1980 to 0.001 million tone in 2016. Sea weed (Nori) 1 billion sheet to 0.01 billion sheet.

Fish production is proportional to population, amount of excreta. Shrimp production by excreta is popular in Vietnam, India and Indonesia and 31000, 30000 and 25000 tone shrimps are exported to Japan respectively in 2015. Peru, Norway and Chile produce much fish by $\mathrm{N}, \mathrm{P}$ caused by counter current of nutrient rich deep sea water with nutrient poor shallow sea water.

Fish production is proportional to $\mathrm{CO}_{2}$ fixed by $\mathrm{CO}_{2}$ assimilation at sea, the country having high fish production is the country which have done high $\mathrm{CO}_{2}$ fixing. 10 times of $\mathrm{CO}_{2}$ of fish production are fixed by plankton $\mathrm{CO}_{2}$ assimilation. China produced 79.38 million tone fish in 2016. This means that China fixed 8 billion tone $\mathrm{CO}_{2}$ by plankton $\mathrm{CO}_{2}$ assimilation. This is huge amount. This is $1 / 12$ of 100 billion tone $\mathrm{CO}_{2}$ produced at China. China is biggest $\mathrm{CO}_{2}$ producing country.

This data indicates that plankton $\mathrm{CO}_{2}$ assimilation is playing significant role for the fixing of $\mathrm{CO}_{2}$ and protection of global warming. Decrease of 12 million tone fish at Japan means decrease of 120 million tone $\mathrm{CO}_{2}$ fixing. If Japan stop elimination of 3 million tone $\mathrm{N}$ and $\mathrm{P}$, Japan can fix 46 million tone $\mathrm{CO}_{2}$ and can produce 12 million tone fish decrease of half million tone fish at Set inland sea means decrease of 5 million tone $\mathrm{CO}_{2}$ fixing.

Japan is most $\mathrm{CO}_{2}$ increasing country, because country is narrow and cannot fix produced $\mathrm{CO}_{2}$ at land (11). Therefore, Japan must fix $\mathrm{CO}_{2}$ by promotion of $\mathrm{CO}_{2}$ assimilation at sea. Japan is producing $10 \% \mathrm{CO}_{2}$ of total $\mathrm{CO}_{2}$ production for the elimination of NOx and drainage treatment. Japan must diminish $\mathrm{CO}_{2}$ emission by stopping NOx elimination, and promote $\mathrm{CO}_{2}$ assimilation and fish production. If governments think $\mathrm{CO}_{2}$ diminish is most important subject, they should consider sea as firm of fish, firm to fix $\mathrm{CO}_{2}$. They should increase $\mathrm{N}, \mathrm{P}$ concentration of sea by releasing $\mathrm{NOx}$ and drainage $\mathrm{N}, \mathrm{P}$ as it is.

\section{Summary}

NOx is a gift from nature. We should not against nature. We should use NOx as it is. NOx is hated as pollution gas causing illness. Many governments set up very strict law to eliminate all NOx in burned gas and forced to eliminate NOx using ammonia. When NOx is released at no person district such as sea side, NOx do not give any harm. One molecule of NOx can fix 25 molecules of $\mathrm{CO}_{2}$ and can protect global warming. I wish to insist that $\mathrm{NOx}$ elimination should be stopped. Because toxicity of NOx is not so serious compared with significant merit of NOx. NOx is essential for the promotion of $\mathrm{CO}_{2}$ assimilation, for the production of foods, for the promotion of health and long life [39-45]. for the protection of global warming.

\section{References}

1. Ozaki Shoichiro (1993) Recycle of nitrogen and phosphorous for the increase of food production New Food Industry 10: 33-39.

2. Ozaki Shoichiro (2016) Methods to protect global warming. Adv Tech Biol Med 4: 181.

3. Ozaki Shoichiro (2016) Methods to protect global warming, Food production increase way. New Food Industry 8: 47-52.

4. Ozaki Shoichiro (2016) Global warming can be protected by promotion of $\mathrm{CO}_{2}$ assimilation using NOx. Journal of Climatology \& Weather Forecasting 4: 2

5. Ozaki Shoichiro (2016) Global warming can be protected by promotion of plankton $\mathrm{CO}_{2}$ assimilation. Journal of Marine Science: Research \& Development 6: 6 .

6. Ozaki Shoichiro (2017) Method to protect global warming by promotion of $\mathrm{CO}_{2}$ assimilation and method to reactivate fish industry. New Food Industry 3: 61-70.

7. Ozaki Shoichiro (2017) NOx is Best Compound to Reduce $\mathrm{CO}_{2}$. Eur J Exp Biol 7: 12.

8. Ozaki Shoichiro (2017) Protection of global warming and burn out of fossil fuel by promotion of $\mathrm{CO}_{2}$ assimilation. $\mathrm{J}$ of Marine Biology \& Oceanography 6: 2 .

9. Ozaki Shoichiro (2017) Promotion of $\mathrm{CO}_{2}$ assimilation supposed by NOx is best way to protect global warming and food production. Artiv of Pet-Envilron Biotechnol 2: 110.

10. Ozaki Shoichiro (2017) Promotion of $\mathrm{CO}_{2}$ assimilation supported by $\mathrm{NOx}$ is best way to protect global warming. J Marine Biol Aquacult 3: 2.

11. Ozaki Shoichiro (2017) Stopping of NOx elimination is easy way to reduce $\mathrm{CO}_{2}$ and protect global warming $\mathrm{J}$ Environ Sci Public Health 1: 24-34.

12. Ozaki Shoichiro (2017) Effective uses of NOx and drainage are clever way to protect global warming and to increase fish production. Oceanography 6 Fisheries $4: 4$

13. Falkowski PG (1994) "The role of phytoplankton photosynthesis in global biogeochemical cycles" (PDF). Photosyntheis Research 39: 235-258.

14. Falkowski PG, Ziemann D, Kolber Z, Bienfang PK (1991) Nutrient pumping and phytoplankton response in a subtropical mesoscale eddy. Nature 352: 52-58.

15. Falkowski PG, Wilson C (1992) Phytoplankton productivity in the North Pacific Ocean since 1900 and implications for absorption of anthropogenic CO2. Nature 358: 741-743.

16. Chisholm SW, Falkowski PG, Cullen JJ (2001) "Dis-crediting ocean fertilization". Science 5541: 309-310.

17. Aumont O, Bopp L (2006) "Globalizing results from ocean in situ iron fertilization studies". Global Biogeochemical Cycles 20: 2.

18. How much do oceans add toward oxygen? Earth \& Sky. 
Citation: Ozaki S (2017) NOx Elimination and Drainage NP Elimination Should Be Stopped for The Production of Fish and for The Protection of Global Warming. J Fish Aqua Dev: JFAD-125.

19. John R (2004) "Source of Half Earth's Oxygen Gets Little Credit”. National Geographic News.

20. Tappan, Helen (1968) "Primary production, isotopes, extinctions and the atmosphere". Palaeogeography, Palaeoclimatology, Palaeoecology 4: 187-210.

21. Wang G, Wang X, Liu X, Li Q (2012) Diversity and biogeochemical function of planktonic fungi in the ocean. In: C. Raghu Kumar (ed.), Biology of marine fungi. Springer Berlin Heidelberg 53: 71-88.

22. Omori M, Ikeda T (1984) Methods in Marine Zooplankton Ecology. Malabar, USA: Krieger Publishing Company 2: 562.

23. NASA Satellite Detects Red Glow to Map Global Ocean Plant Health" (2009) NASA.

24. Satellite Sees Ocean Plants Increase, Coasts Greening" (2005) NASA.

25. Richtel M (2007) "Recruiting Plankton to Fight Global Warming". New York Times.

26. Robert CJ, Lovelock JE, Andreae MO, Warren SG (1987) "Oceanic phytoplankton, atmospheric sulphur, cloud albedo and climate". Nature 326: 655-561.

27. Quinn PK, Bates TS (2011) "The case against climate regulation via oceanic phytoplankton sulphur emissions". Nature 480: 51-56.

28. Calbet A (2008) "The trophic roles of micro zooplankton in marine systems". ICES Journal of Marine Science 65: 325-331.

29. Arrigo, Kevin R (2005) "Marine microorganisms and global nutrient cycles". Nature 437: 349-355.

30. Fanning KA (1989) "Influence of atmospheric pollution on nutrient limitation in the ocean". Nature 339: 460-463.

31. Sterner RW, Elser JJ (2002) Ecological Stoichiometry: The Biology of Elements from Molecules to the Biosphere. Princeton University Press: 464

32. Klausmeier CA, Litchman E, Levin SA (2004) "Phytoplankton growth and stoichiometry under multiple nutrient limitation". Limnology and Oceanography 49: 1463-1470.
33. Klausmeier CA, Litchman E, Daufresne T, Levin SA (2004) "Optimal nitrogen-to-phosphorus stoichiometry of phytoplankton". Nature 429: 171-174.

34. Boyce DG, Lewis MR, Worm B (2010) "Global phytoplankton decline over the past century". Nature 466: 591-596.

35. Schiermeier Q (2010) "Ocean greenery under warming stress". Nature.

36. Mackas DL (2011) "Does blending of chlorophyll data bias temporal trend?". Nature 472: E4-E5.

37. Rykaczewski RR, Dunne JP (2011) "A measured look at ocean chlorophyll trends". Nature 472: E5-E6.

38. McQuatters-Gollop A, Reid PC, Edwards M, Burkill PH, Castellani C, Batten, et al. (2011) "Is there a decline in marine phytoplankton?". Nature 472: E6-E7.

39. Shoichiro O (2015) Sulfo disaccharides co-working with Klotho. Studies on structure, structure activity relation and function World $\mathrm{J}$ of Pharmacy and Pharmaceutical Sciences 4: 152-175.

40. Shoichiro O (2016) Secret of Anti-aging: Anti-Aging Food Containing Glucosamine, Hyaluronic Acid and Chondroitin. Jacobs Journal of Physiology 2: 013.

41. Shoichiro O (2015) Glucosamine Derivatives. Sulfo disaccharides coworking with Klotho. Nutrition and Food Science 5: 416.

42. Shoichiro O (2015) Synthesis of Anti-Aging Reagent: Sulfo Disaccharide Co-working with Anti- Aging Gene. Archives of Medicine 6: 17.

43. Shoichiro O (2015) Nutrition for Good Health, Anti-aging and Long Life, Hyaluronic Acid. Glucosamine and Chondroitin. Maternal and Pediatric Nutrition Journal 1: E102.

44. Shoichiro O (2016) Food containing hyaluronic acid and chondroichin is essential for anti-aging. International Journal of aging \& Clinical Research 1: 101.

45. Shoichiro O (2016) Toward Anti-Aging and Long Life. Jakobs Journal of Physiology 2: 13-17. 